\title{
Foreign Capital Flows and Stock Market Capitalization at the Nairobi Securities Exchange, Kenya
}

\author{
Cliff Osoro $^{1} \quad$ Eddie Simiyu $\mathrm{PhD}^{2} \quad$ Job Omagwa $\mathrm{PhD}^{3}$ \\ 1.Phd Student, Kenyatta University-School of Business, P O Box 43844-00100 Nairobi, Kenya \\ 2.Lecturer, Kenyatta University-School of Business, P O Box 43844-00100 Nairobi, Kenya \\ 3.Lecturer, School of Business, Kenyatta University P O Box 43844-00100 Nairobi, Kenya
}

\begin{abstract}
Since the onset of financial markets liberalization in the early 1990s, the volume of capital inflows to emerging capital markets has grown to unprecedented levels. Despite growth in capital flows, emerging capital markets are characterized by small size and very low liquidity. In the period 2008-2018, the number of listed firms at the Nairobi Securities Exchange increased only by twelve firms from 55 listed firms in the January 2008 to 67 listed firms as at December 2018 giving an average annual increase of approximately one firm per year. This study therefore sought to establish the effect of foreign capital inflows on stock market capitalization at the Nairobi Securities Exchange, Kenya. The study adopted a causal research design and time series data for the period 20082018 was analysed using correlation analysis, and the Autoregressive Distributed Lag Model. The findings from correlation analysis indicate that foreign direct investment had a negative and significant effect on stock market capitalization while foreign equity portfolio inflows had negative but insignificant effect on stock market capitalization at the Nairobi Securities Exchange, Kenya. The autoregressive distributed lag test results support the existence a significant short run positive effects of all foreign capital inflows on stock market capitalization as evidenced by the negative and significant coefficient of the Error Correction Term (ECT). However, in the long run foreign direct investment had a significant negative effect on stock market capitalization while the effect of foreign equity portfolio on stock market capitalization was equally negative but insignificant in the long run. In view of the foregoing findings, there is need for the Kenyan government to reconsider its foreign investment policy to target only productive foreign capital inflows. Moreover, the Capital Markets Authority needs to implement policy measures that will attract active participation of the local investors at the Nairobi Securities Exchange.
\end{abstract}

Keywords: Foreign Capital Inflows, Stock Market capitalization and Nairobi Securities Exchange (NSE).

DOI: $10.7176 / \mathrm{EJBM} / 12-26-07$

Publication date:September $30^{\text {th }} 2020$

\subsection{Introduction and Background}

Development of financial markets leads to improved quality and quantity of investments thus quicken the pace of economic growth and improves the living standards of the citizens (Nera \& Eke, 2017). Emerging capital markets are typically characterized by a small number of listing, lack sophisticated infrastructure and have a narrow range of tradable instruments (Hearn \& Pearse, 2006). Further, the emerging capital markets are characterized by small capitalization and low liquidity levels (Aduda et al., 2012). The Kenyan stock market is not exceptional from the other emerging African capital markets. According to Nyangoro (2013), the Nairobi Securities Exchange market is characterized by small size and very low liquidity. Further, the stock market demonstrates significant structural and regulatory weaknesses (Ngugi, Amanja \& Amana, 2013). In the period 2008-2018, the number of listed firms at the Nairobi Securities Exchange (NSE) increased by twelve firms from 55 listed firms in the January 2008 to 67 listed firms as at December 2018 giving an average annual increase of approximately one firm per year (CMA, 2018). This number of listed firms is very low in comparison to other African Markets like the Nigeria Stock Market with 170 firms, Johannesburg Stock Exchange with 379 firms and the Egyptian Exchange Market with 221 firms as at December, 2018 (World Bank, 2018).

Foreign investors' participation in the stock market is an important source of capital in the stock market. This is attributed, but not entirely, to the fact that foreign investors, unlike the domestic investors who often buy and hold stocks, are likely to trade in the instruments thus improving the market liquidity and hence development of the stock market (Kumar \& Devi, 2013). Moreover, the significant role of foreign financial inflows towards stock market capitalization is attributed the fact that foreign capital inflows increases the depth and breadth of the stock market consequently enhancing stock market size and liquidity. Besides, increased foreign capital flows eventually encourage the political elite to review regulations on foreign investors' protection further leading to increased stock market capitalization. Such improved regulations include amendment of exchange control act that allowed foreign investor participation at the Nairobi Securities Exchange market (Ngugi, 2005).

Before the onset of liberalization in the mid-1990s, Kenya was characterized by very low foreign capital inflows due to the closed capital account operated during the period (World Bank, 2016). However, following the introduction of liberalization there has been increased foreign capital inflows into the country. However, the steady increase in foreign capital inflows was disrupted in the years 1997 and 2008. This can be partly attributed to the 
uncertain political environment due to the aftermath effects of the 1997 and 2007 general election and the global financial crisis of 2008 (Chui, 2016). The increase of foreign financial inflows in 2009 can be partly attributed to renewed investor confidence in the country's political stability. Subsequently, there has been increased volatility in foreign financial inflows hence forming the motivation for the selection of the period 2008-2018 for the purpose of this study.

The years 2008, 2011, 2013, 2017 and 2018 are characterized by negative foreign equity portfolio flows and Foreign Direct Investment. This implies foreign sales were higher than the foreign purchases during this period. This is an indication of a pull out of foreign investors from the domestic stock market. According to Nyangoro (2013) this is attributed to the fact that the foreign investors, who had no prior knowledge of the market, were able to get information of the market and started pulling out immediately they realized that they could not get the returns initially anticipated. The decline in foreign direct investment can be partly attributed to reduced investor confidence due to corruption, insecurity, poor infrastructure high utility cost, interest rates and poor legal framework (Mwega \& Ngugi, 2009).

\subsection{Statement of the Problem}

The main objective of the medium term plan for the capital markets under vision 2030 was to mobilize savings so as to realize a savings to Gross Domestic Product (GDP) ratio of between 25-28 percent (Republic of Kenya, 2007). However, the data from the Kenya National Bureau of Statistics indicate that savings to GDP ratio has been declining and was reported at $12.34 \%, 11.2 \%$ and $10.3 \%$ for the years 2016, 2017 and 2018 respectively (Republic of Kenya, 2018). Hence, the stock market has therefore failed to make significant contribution towards economic growth in Kenya. In the period 2008-2018, the listed firms at the NSE increased marginally by 12 firms from 55 firms listed firms as at January 2008 to 67 listed firms as at December 2018 giving an average increase of one firm per year (CMA, 2018). This number is very low in comparison to other African Markets such as the Nigeria Stock Market with 170 firms, Johannesburg Stock Exchange with 379 firms and the Egyptian Exchange Market with 221 firms as at December, 2018 (World Bank, 2018). The worst decline however is experienced in the year 2018 with a loss in market capitalization of Kshs. 419 Billion. the market capitalization declined by over Kshs.400 Billion from Kshs. 2521 Billion in 2017 to Kshs. 2102 Billion in 2018 (NSE, 2018). During this period, foreign investors' flight from the Nairobi Securities Exchange, attributed to the aftermath of the prolonged 2017-2018 general elections wiped out a significant portion of investor wealth pushing the stock market to the lowest point in over a decade (NSE, 2018). Such huge decline in a single period intensifies the market risk making the market unpredictable and hence unattractive to potential investors (Koskei, 2017).

Despite the theoretical link between foreign capital inflows and development of stock markets, the nature of relationship in the context of NSE remains an issue of empirical investigation and therefore forms the motivation of the current study. Most empirical studies conducted globally on the effect of foreign capital inflows on stock market capitalization indicate a significant relationship with a few studies indicating insignificant relationship between foreign financial flows and market capitalization (Arcabic et al., 2012; Adam \& Tweneboah, 2009; Soumare \& Tchana, 2011). Previous studies have therefore failed to provide unambiguous conclusions on the question of the effect of the various components of foreign financial inflows on Stock Market capitalization. Besides, a significant number of previous studies are conducted in developed capital markets (Malik, 2013; Raza and Jawaid, 2014; Kaleem \& Shahbaz, 2008; Arcabic et., al,2012). Understandably, the context in these markets is different from the stock market context in the emerging African markets. Additionally, majority of these studies tend to emphasize the short run relationship between foreign capital inflow and stock market capitalization notwithstanding the fact that increased stock market capitalization is a long term process. Consequently, creates the need to test the long term effects of foreign capital inflows on stock market capitalization in context of emerging stock markets such as the NSE market.

\subsection{General Objective}

The general objective of the study was to assess the effect foreign capital inflows on stock market capitalization at the Nairobi Securities Exchange, Kenya.

\subsubsection{Specific Objectives}

The specific objectives of the study were:

i. To establish the effect of foreign direct investment on stock market capitalization at the Nairobi Securities Exchange, Kenya.

ii. To determine the effect foreign equity portfolio on stock market capitalization at the Nairobi Securities Exchange, Kenya.

\subsubsection{Research Hypotheses}

$\mathbf{H}_{01}$ : Foreign direct investment has no significant effect on stock market capitalization at the Nairobi Securities Exchange, Kenya.

H02: Foreign equity portfolio has no significant effect on stock market capitalization at the Nairobi Securities 


\section{Exchange, Kenya.}

\subsection{Theoretical Literature Review}

This section provides a review of the relevant theories that support the relationship between foreign financial inflow and development of stock markets. Hence, the FDI Dependency Theory and the Neo Classical Theory of Investment theories were applied to explain the relationship between foreign capital inflows and stock market development.

FDI Dependency theory was formulated by Todaro \& Smith (2003), contends that excessive reliance on foreign direct investment leads to FDI dependency. The theory is premised on the fact that foreign firms, often from advanced markets, possess superior advantage over the domestic firms in developing markets. Multi-National Companies (MNCs) have a greater competitive advantage due to greater technological Knowledge, managerial skills, industrial organization and product knowledge. Equally, MNCs will enjoy greater economies of scale as compared to local firms (Idenyi et al., 2016). Economies of scale enhance the reduction in the cost per unit of services such as financial services, marketing, and cost of technological research. Foreign plants often produce similar products to the domestic market. Thus multi-national companies can even out the effects of economic cycles in various markets by reorganizing the sales across the various destinations in foreign countries (Shenkar, 2007). Therefore foreign firms are able to operate more profitably than the domestic firms and hence have the ability to drive the out the small and medium local enterprises characterized with inferior technology.

The Neo classical theory of investment, also referred to as the Post Keynesian theory of investment, was originally introduced by Gordon (1992). The theory contends that portfolio flow in response to the rate of return differential between regions. Multi-national companies are thus arbitrageurs who take advantage of the locational differences in interest rates in various countries to move capital from low return to high return countries. This theory therefore contends that if the return on equity investment in the stock market is high, such a market is likely to attract more foreign investment as compared to a market with low return on investment. Foreign investors, who are mostly driven by the need to diversify their risk portfolio, take advantage of the high short run return in emerging markets (Allen et al., 2010). However, market stability in the long run leads to spontaneous reversals of foreign portfolio flows. Such spontaneous reversal intensifies markets volatility susceptibility of the market to global economic crisis (Koskei, 2017).

\subsection{Empirical Literature Review}

Arcabic, Globan and Raguz (2012) used the two variable co integration approaches to determine the long-term relationship between the variables. The findings of the study indicated the absence of a long-term relationship among observed variables. Hence, lack of connection between FDI and stock market capitalization in Croatia. To determine the short-run relationship between variables the study used the VAR model. The findings indicated consistency with theoretical assumptions, since FDI proved to be an important short-term determinant of stock market capitalization in Croatia. The study employed cointergration and Vector Auto Regressive (VAR) model and therefore there is need to test the same relationship in a different market context using ARDL bound testing for long run relationship between foreign capital inflows and stock market capitalization.

Adam and Tweneboah (2009) used the multivariate cointegration and innovative accounting methods to study the impact of FDI on stock market capitalization in Ghana. Impulse responses and variance decomposition in VECM were applied in the study. The study findings indicated a significant relationship between the FDI and stock market capitalization in Ghana. This study only considered the impact of FDI thus creating the need to consider more variables that may influence stock market capitalization. Equally, the study only considered the short term relationship thus creating the need to consider the long term relationship between foreign capital inflows and stock market capitalization in the using the autoregressive distributed lag model.

Adebisi, Adesola and Arikpo (2017) examined the relationship between foreign portfolio investment and financial market performance in Nigeria. The study specifically assessed whether there is long run and short run causal relationship running from financial market performance to foreign portfolio investment in Nigeria. Financial market performance was measured using stock market performance, stock market liquidity and total new issues. Findings from the analyses showed that financial market performance has no long run causal relationship with foreign portfolio investment in Nigeria. Equally, stock market performance and stock market liquidity had no short run causal relationship with foreign portfolio investment in Nigeria. Lastly, total new issue had a short run causal relationship with foreign portfolio investment in Nigeria. Current study applied the ARDL model to test both long run and short run relationship simultaneously and equally considered the effect of Foreign Direct Investment on stock market development.

Nwiado and Deekor (2013) investigated the relationship between foreign investments in the domestic bond market and development of the Nigerian capital market. Annual time series data for the period 1981-2007 was analyzed using multiple linear regressions. The findings from the study indicated that foreign participation in the domestic bond market contributes nothing to liquidity of the market and therefore contradicting existing theoretical 
assertion that foreign participation increases market liquidity. This study equally employed multiple linear regressions. However financial relationships are dynamic in nature. Therefore, creating the need to test the same relation in a different context using ARDL bound testing to explore both the long run dynamic linkage between foreign capital inflows and stock market capitalization at the Nairobi Securities Exchange.

Mandaci et. al.,(2013) sought to analyze the factors that determine stock market capitalization the period 1960-2007 in the long span with evidence drawn from both the emerging and developed capital markets. The explanatory variables were foreign Bank credits to private sector and remittance. The study finding indicated that all variables had significant effect on market capitalization. Therefore there is need to test the same relationship in a different context using ARDL bound testing for long run relationship among variables and equally consider other variables likely to influence stock market capitalization. The study mainly focused on the period before the global financial crisis of 2008. Evidently, there has been increased volatility of both foreign financial flows and performance of financial markets following the aftermath of the global financial crisis.

\subsection{Research Methodology}

The study adopted the positivism philosophy and causal research design to identify the nature and extent of the causality relationship between foreign capital inflows and stock market capitalization in Kenya. Positivism philosophy is a structured scientific approach where findings are independent of the researchers view point (Carson et al., 2001). According to Kothari (2004) the approach is more objective and deals with the use of quantitative tools and techniques that deal with measuring and counting. Causal research is conducted in order to assess the effect of specific changes on existing processes and norms (Trochim, 2006). The causal research design assumes the existence of a statistically significant cause effect relationship between the independent variables and the dependent variable (Saunders, Lewis, \& Thornhill, 2009). The target population of the study was The Nairobi Securities Exchange market. As at December 2018 sixty seven firms were listed at the Nairobi Securities Exchange (NSE, 2018). The choice of targeting the Nairobi Securities Exchange was informed by the easy availability and access of information since market information is open to the general public. The data collected was analyzed using both descriptive and inferential statistics. The study used correlation analysis and the Auto regressive Distributed Lag (ARDL) cointergration analysis with the aid of E-views version 9.5 statistical software.

\subsection{Empirical Model}

The ARDL bound testing developed by (Pesaran and Shin, 1995; Pesaran et al.,2001) was used to establish the long run and short run effect of foreign financial flows on stock market capitalization (Raza \& Jawaid, 2013). The ARDL is appropriate since its applied irrespective of the underlying variables being integrated of order I $(0), \mathrm{I}(1)$ but not I(2). ARDL is more robust and performs better in small samples and large than other cointergration techniques (Kalim \& Shahbaz, 2008). Further, ARDL adjusted with an Error Correction Model (ECM) is applied in testing for both long run and short run dynamics simultaneously (Abubakar \& Danladi, 2018). The ARDL model for the study is given in model 3.1

\begin{tabular}{|c|c|c|c|c|c|}
\hline$\Delta M C A P_{t}=\beta_{0}+\Delta M C A P_{t-p}+\beta_{1} \sum_{t=1}^{n}$ & $\Delta F D I$ & ${ }_{t-p}^{+}$ & $\beta_{2} \sum$ & $n_{t=1}$ & $\Delta F E P_{t-p}+\alpha_{1} \Delta F D I_{t-p}+\alpha_{2} \Delta F E P_{t-p}+$ \\
\hline
\end{tabular}

\section{Where:}

$\Delta$ is the difference operator.

$\beta 1 \ldots . . \beta 5$ are the long run coefficients.

$\alpha_{1} \ldots \ldots \alpha_{4}$ are the short run coefficients.

$\operatorname{lnNASI}_{\mathrm{t}}=$ Natural Log of NSE All Share Index at time $\mathrm{t}$

$\operatorname{lnFDI}_{t} \quad=\quad$ Natural log of Foreign Direct Investment at time $t$

$\operatorname{lnFEP}_{\mathrm{t}} \quad=$ Natural Log of Foreign Equity Portfolio at time $\mathrm{t}$

$\mu_{t} \quad=\quad$ Error term.

ARDL model is thus divided into two parts; the first part of the equation with $\beta 0$ to $\beta 4$ denotes the long run coefficients of the model, while the coefficients $\alpha 1$ to $\alpha 4$ signifies the short run coefficients of the model. Before conducting any conducting any cointergration test on the data collected the researcher determined the optimal number of lags. This is performed whenever the ARDL bound testing is used (Kalim and Shahbaz, 2008). Subsequently, the study conducted diagnostic tests before testing for the existence of long run and short run relationship between the study variables. The study adopted the Wald F- statistic to interpret the relationship between the foreign financial flows and stock market capitalization.

\subsection{Research Findings and Discussion}

The findings include results from both bivariate and multivariate analysis. The bivariate analysis results include the findings from the correlation analysis while the finding from multivariate analysis includes the findings from correlation analysis and the ARDL cointergration test results. 


\subsection{Correlation Analysis Results}

The Karl Pearson correlation matrix is applied to test the relationship between the independent variables and the dependent variables of the study. Table 2 below is a presentation of the findings from correlation analysis.

Table 2: Karl Pearson Correlation Analysis Results

\begin{tabular}{|l|c|c|c|}
\hline & InMCAP & InFDI & LnFEP \\
\hline $\operatorname{lnMCAP}$ & 1 & & \\
& & & \\
\hline $\operatorname{lnFDI}$ & $-0.455^{*}$ & 1 & \\
& $(0.002)$ & & \\
\hline $\operatorname{lnFEP}$ & $-0.412^{*}$ & 0.160 & \\
& $(0.005)$ & $(0.301)$ & \\
\hline
\end{tabular}

Source: Study Data (2019)

From the findings illustrated in Table 2 Foreign Direct Investment (FDI) has a negative significant correlation stock market. This can be attributed to the fact that foreign investors are often driven by the need to diversify their risk portfolio and hence take advantage of the high short run returns in emerging markets (Allen et al., 2010). Consequently, as the markets eventually stabilize in the long run such investors often realize that they may not attain the high returns initially anticipated thus pull out of the market immediately leading to shocks (Koskei, 2017). Further, Foreign Equity Portfolio (FEP) has a negative but significant relationship with market capitalization. The negative relationship between foreign equity portfolio and market capitalization can be attributed to the high volatility associated with foreign equity portfolio flows. Such increased volatility affects the market operations and hence reduced market returns (Barnor, 2014).

\subsection{Cointergration Test Results}

The Autoregressive Distributed Lag (ARDL) bound test proposed by Pesaran and Shin (1999) and Pesaran et al.,(2001) was applied by the study to test for the existence long run cointergration. Unlike other methods of cointergration such as Engle and Granger (1987) and the Johansen test (1991), ARDL is appropriate when the variables are intergrated of order $\mathrm{I}(0)$ or intergrated of order $\mathrm{I}(\mathrm{I})$ but not intergrated of order $\mathrm{I}(2)$. Information about the appropriate number of lags is important since the criteria applied in selection of the appropriate lag length will affect the value of the F-statistic obtained from the model (Shahbaz, 2015). Hence, before estimating the long run coefficients the study determined the optimum number of lags. Table 3 presents the lag length selection criteria applied by the study.

Table 3: Lag Order Selection Criteria

Endogenous variable:lnMCAP $\operatorname{lnFDI} \operatorname{lnFEP}$

Exogenous variables: $\mathrm{C}$

Sample: 2008Q1 2018Q4

Included observations: 41

\begin{tabular}{ccccccc}
\hline \hline Lag & LogL & LR & FPE & AIC & SC & HQ \\
\hline \hline 0 & 40.46720 & NA & $1.22 \mathrm{e}-07$ & -1.730107 & -1.521135 & -1.654011 \\
1 & 194.0311 & 262.1823 & $2.33 \mathrm{e}-10$ & -8.001517 & $-6.747684^{*}$ & -7.544940 \\
2 & 221.8177 & 40.66336 & $2.15 \mathrm{e}-10$ & -8.137450 & -5.838756 & -7.300393 \\
3 & 267.0738 & $55.19036^{*}$ & $9.32 \mathrm{e}-11^{*}$ & $-9.125552^{*}$ & -5.781997 & $-7.908014^{*}$ \\
\hline \hline
\end{tabular}

* indicates lag order selected by the criterion

LR: sequential modified LR test statistic (each test at 5\% level

FPE: Final prediction error

AIC: Akaike information criterion

SC: Schwarz information criterion

HQ: Hannan-Quinn information criterion

The optimum number of lags is selected on the basis of the lowest values of Akaike information criterion (AIC), Schwarz information criterion (SC) and Hannan-Quinn information criterion (HC). From the findings demonstrated in Table 3 the optimal lag length selected was three lags based on the minimum value of AIC, SC and HC. Selection of three lags is equally appropriate since it aids in the reduction of the loss in degrees of freedom 
through exclusion of several observations. Upon selecting the appropriate number of lags, the ARDL bound test was conducted. The Autoregressive Distributed Lag (ARDL) cointergration test results are presented on Table 4.

Table 4: Summary of ARDL Cointergration Test Results

\begin{tabular}{|l|l|l|l|l|}
\hline \multicolumn{2}{|l|}{ ARDL-ECM Coefficients (Dependent Variable: Market Capitalization) } \\
\hline & Short Run Coefficients & Long Run Coefficients \\
\hline Variable & Coefficient & Prob & Coefficient & Prob. \\
\hline lnFDI & Positive & $0.0476<0.05$ (significant) & Negative & $0.0470<0.05$ (significant) \\
\hline lnFEP & Positive & $0.0417<0.05$ (significant) & Negative & $0.2395>0.05$ (Insignificant) \\
\hline ECT & -0.7502 & $0.0001<0.05$ (significant) & & \\
\hline
\end{tabular}

\section{Source: Study Data (2019)}

Table 4 above indicate that all the study variables have a significant positive short run effect on market capitalization as an indicator of stock market development. However, in the long run foreign direct investment has a significant long run negative effect on stock market capitalization while foreign equity portfolio has no significant effect on stock market capitalization in the long run. The coefficient of the Error Correction Term (ECT) indicates the speed at which the model adjusts to long run equilibrium while the sign of the ECT indicates the direction of adjustment to equilibrium (Pesaran et al., 2001). According to Shahbaz et al., (2013) the coefficient of the error correction term should be negative and significant to indicate a stable long run equilibrium. A highly significant negative coefficient of the error correction term is an indication of stable long run equilibrium of the model (Bannerjee, Dolado \& Mestre,1998). The findings presented on table 4 above indicates that foreign capital flows have a significant short run effect on market capitalization as evidenced by the negative and significant coefficient of the error correction term of -0.7502 with a 0.0001 probability value less than 0.05 . This implies that model adjusts back to long run equilibrium quarterly at a speed of 72.04 percent.

\subsection{Conclusions, Policy Implications and Recommendations}

The study first sought to establish the effect of foreign direct investment inflow and stock market capitalization at the Nairobi Securities Exchange, Kenya. Foreign Direct Investment had a significant negative long run effect and a significant positive short run effect on market capitalization. The study therefore concludes that an increase in foreign direct investment leads to an increase in the market value at the Nairobi Securities Exchange in the short run. However, increased foreign direct investments leads to a decline in market value, in the long run.

Secondly, the study sought to determine the effect of foreign equity portfolio investment on stock market capitalization. Foreign Equity Portfolio had an insignificant long run effect and a significant short run positive effect on market capitalization. Since Foreign Equity Portfolio had a significant positive short run effect on market capitalization, the study therefore concludes that an increase in foreign equity portfolio leads to an increase in the market value, at the Nairobi Securities Exchange in the short run. However, in the long run, an increased foreign equity portfolio inflow does not have a noticeable effect on market value.

\subsection{Policy Implications and Recommendations}

The foregoing findings indicate that Foreign Direct Investment and Foreign Equity portfolio are highly volatile and have negative and insignificant effects on stock market capitalization. Thus Capital Markets Authority (CMA) needs to devise measures of encouraging the local investors to invest and access funds through the stock market. The CMA needs to implement policy measures that would attract the local small and medium enterprises to have their stocks listed at the stock market. Equally the government should support the domestic firms to expand their operations so as to meet the minimum requirements for enlisting at the stock market. Active participation of the local investors at the Nairobi Securities Exchange will give the bourse more stability and liquidity hence the value of stock will increase.

Secondly, the Kenyan government thorough the ministry of foreign affairs and other government agencies need to reconsider the Kenya foreign investment policy and the effectiveness of each foreign inflow with the sole objective being to attract only productive foreign capital inflows. The foreign investment policy should only target those inflows that have a productive effect on the stock market and other sectors of the economy. More emphasis should be placed on foreign inflows have a high significant positive effect on stock market capitalization

\subsection{Contributions to Knowledge}

Existing literature has associated foreign direct investment with long term stability and a vast range of "spill over" benefits including: employment creation, technological spill over, human capital development, quality productivity, creation of competitive business environment and the enhancing of enterprise development. Further, existing literature suggests that increased foreign direct investment would increase capital availability thus stimulate goods and services production leading to increased income in the domestic economy. However, contrary to existing literature the findings in the current study confirm that foreign direct investment has a negative long run effect on stock market development at the Nairobi Securities Exchange market. The study equally indicates 
that despite the significant increase in foreign equity flows, its contribution to stock market development in the long run is insignificant.

\section{REFERENCES}

Abubakar M and Danladi U. (2018). Foreign Direct Investment and Stock Market capitalization in Nigeria: Evidence from ARDL Bound Test Approach to Cointegration Journal of Economics and Finance 9 (79-85).

Adam, A. M. and Tweneboah, G. (2009). Foreign Direct Investment and Stock Market Development: Ghana's Evidence. International Research Journal of Finance and Economics, 26.

Adams, S. (2009). Foreign Direct Investment, Domestic Investment and Economic Growth in Sub Saharan Africa. Journal of Policy Modeling, 31(939-949).

Adjasi, K. C., and Biekpe, N. (2006). Stock Market capitalization and Economic Growth: The Case of Selected African Countries," African Development Review, 18 (1):144-161

Adebisi Adesola and Arikpo (2017). Financial Market Performance and Foreign Portfolio Inflows to Nigeria: Autoregressive Distributive Lag Approach. International Journal of Research-Granthaalayah ., 5 (6).

Adenuga (2010). Stock Market capitalization Indicators and Economic Growth in Nigeria. Central Bank of Nigeria economic and financial Review 48(11).

Adesola W. Adebisi, and Oka Felix Arikpo. (2017). Financial Market Performance and Foreign Portfolio Inflows to Nigeria: Autoregressive Distributive Lag Approach. International Journal of Research - Granthaalayah, 5(6), 673-688.

Aduda, J., Masila, J. M., and Onsongo, E. N. (2012). The Determinants of Stock Market Development: The Case for the Nairobi Stock. International Journal of Humanities and Social Science, 2(9) 214-227.

Alber R.Z(1970) A Theory of Direct Foreign Investment. The International Cooperation M.T Press, Cambridge M.A USA.

Alber, R. Z. (1980). 'A Conceptual Approach to the Analysis of External Debt of the Developing Countries'. World Bank Staff Working Paper No. 421. Washington, DC: World Bank.

Anokye, M. and Tweneboah G. (2009). Foreign Direct Investment and Stock Market capitalization: Ghana's Evidence, International Research Journal of Finance and Economics, 26, 179-185.

Arcabic, Globan and Rajaz (2012). The Relationship Between the Stock Market capitalization and Foreign Direct Investment in Croatia: Evidence from VAR and Cointergration Analysis. Financial theory and practice, 109126.

Arnold, G. (2008). Corporate Financial Management. 4th ed. Harlow: Prentice-Hall.

Bannerjee, A., Dolado, J. and Mestre, R. (1998):"Error Correction Mechanism Tests for Cointegration In Single Equation Framework." Journal of Time Series Analysis 19, 267-283.

Barney B(1991). Firm Resources and Sustained Competitive Advantage "Journal of business Management” 17(1).

Barnor, C. (2014). The Effect of Macroeconomic Variables on Stock Market Returns in Ghana. Walden university.

Basemera S. and Mutenyo J.(2012). Foreign Direct Investment to East Africa: Do institutions Matter? Journal of Business Management and Applied Economics, 5.

Bayar Y. (2016). Foreign Capital Inflows and Stock Market capitalization in Turkey. Springler International Publishing.

Blumberg, B., Cooper, D. R., \& Schindler, P. S. (2011). Business Research Methods (3rd Ed.). London: McgrawHill Higher Education.

Boboye, Oluwakemi and Alamu (2017) Impact of Foreign Private Investment on The Development of Nigerian Capital Market. International Journal of Economics, Business And Management Research, 1(2) 2456-7760.

Bradley M., Greg A., Jarell E., Kin H.(1984). The Existence of an Optimal Capital Structure: Theory And Evidence. Journal of Finance. 39(3): 857-868.

Brooks.C.(2008) Introductory Econometrics For Finance. $2^{\text {nd }}$ Edition, Cambridge University Press New York

Bucley And Cusson(2009). Internationalization Theory of A Multinational Enterprise. Journal of International Business Studies. 1563-1580.

Capital Markets Authority (2017). Statistical Bulletin. Retrieved From www.cma.or.ke.

Carson, D., Gilmore, A., Perry, C., \& Gronhaug, K. (2001). Qualitative Market Research. London: Sage.

Choi, I. (2001). Unit Root Tests For Panel Data. Journal of International Money and Finance, 20,249-272.

Chui (2016). Analysis of The Nairobi Stock Exchange: 2008-2016. Dyer And Blair Investment Bank.

Cooper, R. D., and Schindler, S. P. (2008). Business Research Methods. India: Tata MCP Graw-Hill.

Desai M.A And Foley C.F.(2005) Foreign Direct Investment and Domestic Capital Stock. American Economic Review 33-38.

Dickey DA, Fuller WA (1981) Likelihood Ratio Statistics for Autoregressive Time Series with A Unit Root. Econometrica 49 (4):1057-1072.

Engle RF, Granger C (1987). Co-Integration and Error Correction: Representation, Estimation and Testing. Econometrica Pp.251-276. 
Fama, E., \& K.R. French. (2002). Testing Trade-Off And Pecking Order Predictions About Dividends And Debt. Review Of Financial Studies, 15, 1-33.

Frankel J. and Saravelos G. (2012) Can Leading Indicators Assess Country Vulnerability? Evidence From 20072008 Global Financial Crisis Journal of International Economics 87(2), 216-231.

Gachanja S. And Kosimbei G.(2018). Dynamic Linkage Between Foreign Equity Flows And Stock Market Returns At Nairobi Securities Exchange. Strategic Journal of Business Change Management. 5(3)

Granger C.J (1969) Investigating Causal Relationships By Econometrics Models And Cross-Spectral Methods. Econometrica 37(3):424-438.

Gordon M.J (1992). The Neo Classical and Post Keynesian Theory of Investment. Journal of Post Keynesian Economics 14:4, 425-443.

Gordon. M.J (2015) The Neo- Classical And Post Keynesian Theory of Investment. Journal of Post Keynesian Economics, 14(4) 425-443.

Greene, W.H. (2008). Econometric Analysis (6th Ed.), Upper Saddle River, New Jersey, USA: Prentice Hall.

Gujarati, D. (2003). Basic Econometrics (4th Ed.), New York, USA: Mcpgraw Hill.

Hearn, B., and Piesse, J. (2010). Barriers to the Development of Small Stock Markets: A Case Study of Swaziland and Mozambique. Journal of International Development. 22, 1018-1037.

Hymer S.H. (1976). The International Operation Of National Firms: A Study Of Direct Foreign Investment, MT Press, Cambridge, MA, United States.

Idenyi. S, Ifeyinwa.C, Obinah. J And Agbi.P (2016). Impact of Foreign Direct Investment On Stock Markets Growth In Nigeria. Asian Research Journal of Arts and Social Science 1-14.

Kaleem, R. And Shahbaz, M. (2009). Impact Of Foreign Direct Investment On Stock Market capitalization: The Case Of Pakistan. $9^{\text {th }}$ Global Conference on Business and Economics, Cambridge University, U.K.

Keynes, J. M. (1936). The General Theory of Employment, Interest and Money, London: Macmillan.

Koskei L, Kibet L And Nyangau A.(2016). A Comparison Of The Effect Of Portfolio Equity On Stock Returns Of Listed Banking And Non-Banking Institutions In Kenya. African Journal of Business and Management 10(22), 569-575.

Koskei (2017). Effect Of Foreign Portfolio Equity Sales On Stock Returns In Kenya: Evidence From NSE Listed Financial Institutions. International Journal of Economics And Finance 4(9).

Kothari, C. R. (2004). Research Methodology: Methods and Techniques. Delhi: New Age International (P) Ltd Publishers.

Mandaci P, Aktan B, Kurt-Gumuş G, Tvaronavičienè M (2013). Determinants of Stock Market capitalization: Evidence from Advanced and Emerging Markets in A Long Span. Journal Business Theory and Practice 14(1), 51-56.

Malik, M.A.R., Chaudhry, A.R. And Mohammed (2012). "Exploring The Link Between FDI, Mnes And Spillover Effects In The Developing Economies", International Journal of Business And Management, 7,230-240.

Malik IA, Amjad S (2013). Foreign Direct Investment and Stock Market capitalization in Pakistan. Journal International Trade Law Policy 12(3):226-242.

Mills, T. C. (1999). The Econometric Modelling of Financial Time Series, 2nd Edn., Cambridge: Cambridge University Press.

Mogaka D. (2017). Short-Term Financing Decisions And Financial Performance of Non-Financial Firms Listed At The Nairobi Securities Exchange, Kenya. Phd Thesis, Kenyatta University. Also available online at http://repository.ku.ac.ke

Mukras, S. (1986). Elements of Mathematical Economics. Kenya Literature Bureau. Nairobi, Kenya.

Munene A.(2016). Financial Deepening and Capital Market capitalization In Kenya. Phd Thesis, Kenyatta University. Retrieved from http://repository.ku.ac.ke

Mungami, E.S (2013). Determinants Of Lease Financing Decisions By Non-Financial Firms Quoted On Nairobi Securities Exchange, Kenya. Phd Thesis, Kenyatta University. Retrieved from http://repository.ku.ac.ke.

Mwangi W.(2014). Effect Of Financing Decisions on The Perfomance of Non-Financial Companies Listed at The Nairobi Securities Exchange Market. Phd Thesis Kenyatta University. Also available online at http://repository.ku.ac.ke.

Mwega F.(2009). Global Financial Crisis Discussion Series Paper 7. Kenya Overseas Development Institute London.

Mwega F.M And Ngugi R.(2009). Foreign Direct Investment in Kenya and Sub Saharan Africa: Origins and Targets, Impacts and Potential. African Research Consortium, 2006 133-157.

Myers. S. (1977). Determinants of Corporate Borrowing. Journal of Financial Economics. 147-175.

Nairobi Securities Exchange (2010). Nairobi Securities Exchange 20 Share Index Listing Manual. Nairobi, Kenya.

Nairobi Securities Exchange (2013a). Nairobi Securities Exchange Launches The Growth Enterprise Market Segment. NSE, Nairobi. Available online (www.nse.co.ke).

Nairobi Securities Exchange (2013b). Listing Of Home Africa At The Nairobi Securities Exchange. NSE, Nairobi 
Available online (www.nse.co.ke).

Nairobi Securities Exchange (2018). Listed Companies. Retrieved From https://www.nse.co.ke/listedcompanies/list.html.

Nairobi Securities Exchange (2016). Annual Reports. Retrieved From https://www.nse.co.ke.

Nairobi Securities Exchange (2018). Quarterly Statistical Bulletin. Retrieved From https://www.nse.co.ke.

Nera and Eze (2017). Stock Market capitalization And Foreign Investor Participation In Nigeria: A Causality Investigation Journal of Finance, Banking And Investment, 4(1).

Newey W. and West K. (1987). "A Simple, Positive Semi-Definite, Heteroskedasticity and Autocorrelation Consistence Covariance Matrix". Econometrica 55(3), 703-708.

Ngugi, R. W. (2003a). Development of the Nairobi Stock Exchange: A Historical Perspective. Kenya Institute for Public Policy Research and Analysis (KIPPRA) Discussion Paper No. 27, Nairobi.

Ngugi, R. W. (2003b). What Defines Liquidity Of The Stock Market? The Case of Nairobi Stock

Exchange. Kenya Institute for Public Policy Research and Analysis (KIPPRA) Discussion Paper No. 29, Nairobi. Ngugi, R. W., and Njiru, R. (2005). Growth of the Nairobi Stock Exchange Primary Market. Kenya Institute for Public Policy Research and Analysis (KIPPRA) Discussion Paper No. 47, Nairobi.

Ngugi And Nyangoro (2005). Institutional Factors and Foreign Direct Investment Flows: Implication For Kenya. Discussion Series Published By KIPPRA.

Ngugi, R., Amanja, D., \& Maana, I. (2009). Capital Market, Financial Deepening And Economic Growth In Kenya. In Centre For The Study Of African Economies Conference, 22-24.

Ngugi R.W, Amanja D and Maana I. (2010). The Capital Market And Economic Growth Kenya: Policies For Prosperity. Oxford University Press.

Nguyen, T. T. (2016). Macroeeconomic Indicators and The Stock Market Development in Emerging Economies: The Case Of Vietnam. London: Cardiff Metropolitan University.

Njoroge W. (2014). Effect of Diaspora Remittance On Stock Market Performance: Evidence

From Nairobi Securities Exchange. International Journal of Current Aspects In Finance (IJCAF), 2(2) 1-11.

Nyangoro, (2013). Foreign Portfolio Flows and Stock Market Performance in Kenya: Case of

Nairobi Securities Exchange. PHD Thesis, University of Nairobi, CSAE Conference on Economic Development in Africa.

Nwiado D. And Deekor L. (2013). The Domestic Bond Market And The Development Of The Nigerian Capital Market: An Empirical Analysis. Journal of Economics and Sustainable Development. 4(7).

Osoro C And Jagongo A. (2014). Investor Perceptives On The NASI And The NSE All Share Index As Perfomance Measurement Indicators At The Nairobi Securities Exchange. International Journal Of Humanities And Social Sciences. 3(18)

Pesaran, M. H, \& Shin, Y. (1999). An Autoregressive Distributed Lag Modeling Approach To

Cointegration Analysis. In Strom S (Ed) Econometrics and Economic Theory in The 20th Century: The Ragnar Frisch Centennial Symposium. Cambridge University Press, Cambridge.

Pesaran, M. H. Shin, Y. \& Smith, R. J. (2000). Structural Analysis Of Vector Error Correction

Models With Exogenous I(1) Variables. Journal Of Econometrics 97(293-343).

Pesaran, M. H. Shin, Y. \& Smith, R. J. (2001). Bounds Testing Approaches To The Analysis Of Level Relationships. Journal of Applied Economics, 16 (289-332).

Phillips PB, Perron P (1988). Testing For A Unit Root In Time Series Regression. Biometrika . 75, 335-346.

Raza SA, Jawaid ST (2014). Foreign Capital Inflows, Economic Growth and Stock Market Capitalization In Asian Countries: An ARDL Bound Testing Approach. Qual Quant 48(1):375-385.

Raza SA, Jawaid ST, Afshan S, Karim MSZ (2015). Is Stock Market Sensitive To Foreign Capital Inflows And Economic Growth? Evidence From Pakistan. Journal of Economic and Foreign Trade 8 (3):142-164.

Raza, A., Iqbal, N., Ahmed, Z., Ahmed, M. And Ahmed, T. (2012). The Role of FDI On Stock Market capitalization: The Case Of Pakistan. Journal of Economics and Behavioral Studies. 4(1) 26-33.

Raza, S. A., And Jawaid, S. T. (2012). Foreign Capital Inflows, Economic Growth and Stock Market Capitalization In Asian Countries: An ARDL Bound Testing approach, Quality And Quantity, DOI: 10.1007/S11135-0129774-4.

Republic of Kenya. (2007). Kenya Vision 2030 - A Globally Competitive and Prosperous Kenya. Nairobi: Government Printer.

Republic Of Kenya. (2018). Kenya Economic Report 2018. Also available online and Retrieved

http://www.knbs.or.ke //Downloads/Kenya Economic Report 2018.Pdf

Saunders M, Lewis P. And Thornhill, A. (2009). Research Methods For Business Studies Fifth Ed Pearson Educational Centre Edinburgh Gate, Harlow, And Essex CM 202 England.

Shahbaz, M. Qureshi, M. N. \& Naveed, A. (2007). Remittances And Financial Sector's Performance: Under Two Alternative Approaches For Pakistan. International Research Journal of Finance and Economics. Issue 12.

Shahbaz M. And Rahman M.M.(2011). The Dynamic Nature Of Financial Development, Imports, Foreign Direct 
Investment And Economic Growth: Cointergration And Causality Analysis In Pakistan. Global Business Review 13, 201-219.

Shahbaz,M., Lean,H. \& Kalim,R.(2013). The Impact Of Foreign Direct Investment On Stock Market capitalization: Evidence From Pakistan, Journal Of Economic Research, 26:1(17-32).

Shahbaz,M., Rehman,I. and Afza,T.(2015). Macroeconomic Determinants of Stock Market

Capitalization in an Emerging Market: Fresh Evidence from Cointegration with Unknown Structural Breaks. Macroeconomics and Finance in Emerging Market Economies, 1-26

Soumare, I. And Tchana, F. M. (2011). Causality Between FDI And Financial Market capitalization: Evidence From Emerging Markets. MPRA 310-328.

World Bank (2018). International Financial Markets Statistics. Http://Data Worldbank.Org/Indicator/

Yartey, A. C. (2008) The Determinants Of Stock Market capitalization In Emerging Economies: Is South Africa Different? IMF Working Paper No. WP/08/32, Washington D.C.: International Monetary Fund. 